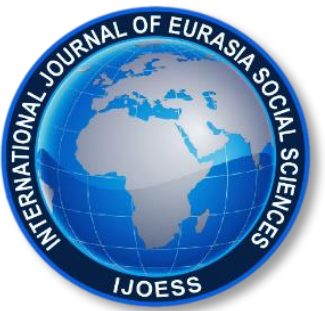

International Journal of Eurasia Social Sciences

Vol: 11, Issue: 39, pp. (118-135).

Article Type: Research Article

Received: 15.03.2019 Accepted: 12.03.2020

\title{
DEMOCRATIC PEACE THEORY AND INTERNATIONAL SECURITY: A CRITICAL PERSPECTIVE
}

\author{
Betül ÇATAL
}

Lecturer, Selçuk University Faculty of Law Vocational School of Justice, Turkey betul.catal@selcuk.edu.tr ORCID: 0000-0002-7154-4975

\begin{abstract}
States, just like humans, primarily strive to survive and maintain territorial integrity. They develop strategies against security threats from inside or outside. These security strategies may vary according to the state's geopolitical and geostrategic structure, economic base, population and perceived threat. Although some tools are different, the aim is usually the same; firstly, it is to keep the state alive without disturbing the territorial integrity of the country by eliminating existing threats and preventing imminent threats and to provide a peaceful and safe life for its citizens. Increased security concerns after the Cold War escalated after the September 11 attacks. There are many tools used to solve international security problems such as war, armaments, and the alliance. It will be examined in this study whether one of these tools, democracy and democratization efforts, can overcome these problems. Also predicted by the democratic peace literature, democratic institutions are the ones that are required for the world to be a peaceful place which forms the basis of another variable whether it is or all of them; and hence the same stability and control as a mechanism of democratic institutions the institutions to work with countries that have another condition that is needed to be able to create peace is necessary, whether answers to questions will be sought.
\end{abstract}

Keywords: International security, democracy, democratic peace, liberalism, war, peace. 


\section{INTRODUCTION}

The analysis of security, which is one of the most policy-driven concepts throughout history, within the scope of international relations discipline, creates the possibility of dealing with all variables from the level of the individual to the level of the system. The correct proportional relationship between change and security also testifies to this process and explains the differentiation in perceptions from an individual level to system level. These distinctions include the expansion, deepening and spread of the concept, in practice (in international politics), and constitute the inclusive agenda that exists in perceptions.

The concept of security in the discipline of international relations is consistent with the development of the discipline. In the field of security, the appropriate ground for conceptual investigations and investigations is formed under this platform. At first, while the main focus of security studies was on war, the scope of international relations discipline has become a peace-oriented field. During the First and Second World War, security was perceived as a multi-disciplinary and multi-dimensional field. Concepts such as international law, international institutions and political theory to support democracy and disarmament have shown itself in the early studies of the discipline.

International security and peace or international conflicts, problems, crises, etc. international insecurity is closely related to each other. In this regard, for example, Michael Lund, there is a very fine line between international peace and international insecurity, and the process of deterioration of international security and the transformation into international insecurity is followed by a linear graph. (Lund, 2006: 141). According to Lund's model, lasting peace in the state of assurance that countries with a sense of "security community", as Karl Deutsch put it, will not engage in military methods against some problems in their relations; this level of relationship reflects the 'peace between democracies' approach. (Işsyar, 2008: 10).

Democratic peace theory, the foreign policy of a state's form of sovereignty he is acting from the acceptance that he has determined his behavior. Regimes accordingly democratic states are prone to peace and are opposed to each other almost they never make war. Thus, democratic regimes have a peaceful content and a peaceproducing characteristic that is not in other forms of sovereignty (Büyükbaş, 2012: 2). When we look at The Theory of democratic peace, the origin of this theory is based on Immanuel Kant's Perpetual Peace. According to Kant, international peace, Republican Constitutions, free trade, and economic independence and a cosmopolitan law embodied by the provision of three elements, international law and organizations can be established (Oneal a.o., 2003: 371).

True peace in the world will only be achieved by the Democratic administrations of all states of the world. However, Immanuel Kant has opposed unlimited freedom understanding that states can do whatever they want. A perfect constitutional order must be established, and the foreign Relations of states must be based on the law. It will not be possible to establish a Democratic Union between states until this problem is resolved (Grayson, 2003: 2). 
The leaders of Democratic states are restricted to the use of force against other democracies about how to contact. By promoting democracy and individual freedoms and responsibilities, it enables entrepreneurship and expansion of trade beyond the borders of a country. The economic activities of citizens make states interdependent, and in this respect, international law and organizations are needed to regulate trade and interdependence (Oneal a.o., 2003: 382).

According to the popular understanding of the writings of Michael Doyle in the 1980s, liberal democratic states can establish peaceful relations with each other, but liberal and/or non-democratic regimes tend to continue wars. Because of the basic points of the Democratic Peace Theory, democracies are peaceful unless they are attacked or threatened by authoritarian regimes. Democracies only resort to the use of force when it is a direct and real threat to the democratic lifestyle they maintain. Democracies, as their definition suggests, do not fight each other. The most effective way to achieve global stability and peace is to spread democracy (Farhnam, 2003: 398).

In previous studies, the vision of Peace Studies and its intellectual foundations and its continuing theses were analyzed and no assessment was made in terms of security. Therefore, the study is very important in terms of evaluating the effects of the democratic peace theory on international security. In this study, after drawing a general theoretical framework of the concept of security in the first part, after examining democracy and democratic peace theory in the second part, the third part will look for answers to the question of whether to use democracy as a tool in solving international security problems.

\section{Security}

\section{What Is Security?}

The concept of security is a term used in every individual and social phase of human life since birth. In this case, it can be considered as a vital necessity to a great extent. Considering the type of child safety, Family Safety, Building Safety, company Safety, State safety, it is clear that there is a serious security search in every aspect of individual and social life. For an individual, security represents the whole of concern at various levels. It is the main concern that their relatives and their lives are safe, that their property is safe, and that this safe situation is maintained. For example, did the concern of man to provide shelter, to protect the shelter from natural disasters or "other" disasters, and to constantly make the equipment and material that would serve to sustain life in the shelter and to develop it, not the suppository of his evolution? Can't it be argued that the search for security doesn't make a difference, even though many things separate the people who set fire to protect their shelter from predatory animals, from the people who insure their home to a multinational insurance company? (Dedeoğlu, 2003: 9)

An attempt to redefine the concept of "security" has recently become an industry for this discipline. However, much of such efforts are concerned with redefining the national States ' policy agenda rather than with the 
concept of security itself. In general, it is seen that the traditional concerns about security from external military threats such as human rights, economy, politics, environment, drug trafficking, epidemics, crime or social injustice are increasing. (Baldwin, 1995: 5).

The concept of security has been defined by many thinkers in different ways. Some of these definitions are as follows: Arnold Wolfers "Security is not a threat to the values at hand in the objective sense, and in the subjective sense it is not a fear that there will be an attack on those values" (Buzan, 1991: 17). Carlo Masala: "Security is a struggle against threats to reduce living standards of citizens of a state and threats that narrow down the decision-making options of governments and non-governmental organizations" (Masala, 1999: 80). Richard Ulman:" Security is the absence of an attack or threat to the values or standards of life of individuals, nongovernmental units, groups or states" (Levy, 1995: 40). Thomas F. Homer-Dixon: "Security is the protection of the physical, social and economic well-being of individuals" (Dixon, 1995: 44). Muhammed Ayoob:" Security is the absence of any threat to states 'values, national and theoretical structure and regime" (Ayoob,1995). According to the widely accepted definition, "Security is the ability to maintain the independence and integrity of the state and societies". Global schools emphasize international responsibilities, not nationalists (Mütercimler, 2001: 18).

United Nations Universal Declaration Of Human Rights of 25. everyone has the right to a standard of living adequate for the health and well-being of himself and of his family, including food, clothing, housing, and medical care and necessary social services, and the right to security in the event of unemployment, sickness, disability, widowhood, old age or other lack of livelihood in circumstances beyond his control, motherhood and childhood are entitled. (UNHR,1948).

No matter what form it is, no matter how it is used, no matter how to speak of a security phenomenon; (Gjejlani, 2007: 15).

- An internal threat to the protection and maintenance of an asset (or a few)

- $\quad$ An external threat (or a few)

- $\quad$ There must be perceptions and predictions of this type.

Security has a meaning for priority. The objectives within the framework of the protection and sustenance of existence are similar to the situation in which the individual identifies himself with multiple characteristics. A person can first define himself as a woman, then mother, then banker, then Jew, then French, and the order of precedence varies according to the importance and conditions he gives. (Dedeoğlu, 2003: 9-11).

Events that develop according to time and circumstances have enriched the content of the concept and have changed security formations, methods, and techniques. It is also known that the history of international relations has been largely taken up as a date based on the conflict - reconciliation principle and therefore has become a direct part of the concept of security (Gjejlani, 2007: 18). 


\section{The Concept of Deepening and Expanding Security}

The traditional understanding of security, military security in terms of single a thought that puts the state forward as a legitimate reference object it is formed around (Buzan, 1998: 2). Therefore, the traditional understanding of security according to security, interstate rivalry and strife are related and military threats are the main issues of traditional security understanding. Physical according to the traditional sense of security with an emphasis on security, national the most obvious element of security is the protection of national borders from encroachment by other states. This is a physical value and its absence no other purpose in the case is unsustainable. In this context, to security, the traditional understanding of the field of Security Studies only in the sense of the control, use and threat studies of military force he insists on being identified (Walt, 1991: 212-213).

The starting point of the expansion in the agenda of the Security Studies is the softening period of the Cold War years, and as a result of the developments in the international system after this period, it has increased the diversity of the agenda. In addition to military/strategic security threats, the diversification of security threats has led to the emergence of a dynamic agenda in the international security environment. In this context, the state-based security concept of realist/neorealist circles has been subjected to increasing criticism of new approaches (Ă̆ır, 2014: 104). Besides, for example, during the Cold War, it is claimed that most of the scientific studies of the security concept are merely the studies of scientists who are mostly interested in the military side of the state. When it comes to military power, it is considered a security issue; those not related to military power are included in the category of secondary politics. The concept of security, a flag to be waved, has been a label of security throughout the Cold War, where there is no significant analytical concept for the man to be glued to (Baldwin, 2003: 11).

During the Cold War, one of the most prominent issues outside the military security phenomenon is geopolitical work. After 1945, the formation of communist regimes in eastern Europe, the USA's Vietnam İntervention and containment policy are based on geopolitical concerns. Another dominant security concept during the Cold War is national security.During the Cold War, while states were taking measures by providing their internal security, they were developing a security policy against external threats to the state. National interests and the state's welfare were paramount (Kıyıcı, 2012: 8).

New critical security approaches, traditional security its approach stems from external threats and especially from rival states he criticizes the focus on military threats. According to these approaches, contemporary the origin of security threats is either out of state or due to the state itself. To Benjamin Miller according to the basic security threat, human rights are ethnic, religious and sexual fundamentally infringing and leading to ethnic cleansing and mass deaths it derives from the states themselves (Miller, 2001:19). Other than that, to humanity many threats directed only from aggressive states environmental pollution, starvation, epidemics, natural disasters, human and drug trafficking and weapons of mass destruction it has a global and nation-extreme nature like the problem of its spread (Kreause \& Williams, 1996: 230). 
NATO's new strategic concept in May 2010 published by the group of experts formed as part of their work In the"NATO 2020 Report", in the context of NATO, conventional military attack his threat was deemed unlikely; however, this possibility was ignored. nontraditional towards alliance over the next decade threats seem more likely, of which, in particular, nuclear or non-nuclear war-titled ballistic missile attack, international terror attacks by organizations and cyber attacks of varying intensity in terms of Alliance it is stated to be of special and priority importance. Other than posing a particular risk among the threats, disrupting energy supplies and marine transportation routes suffering, the negative consequences of global climate change and the global financial crisis counted (NATO 2020, 2010: 17).

In international relations, the international security phenomenon, terrorism, proliferation of weapons of mass destruction, organized crime, bad administration, environmental problems, poverty and organized crime are discussed in a much wider context (Tavas, 2012: 8).

\section{Security Concept in International System}

In the international system, security perceptions have gained different content according to different periods and have always been expressed in different ways by each actor. Because there was no threat to damaging each actor at the same intensity, at the same time interval, and at the same intensity. However, security concerns have always existed throughout history, and the concept of threat has been refilled according to each condition. To avoid the "other", to avoid the "other", to avoid the competition with the "other" and even to be superior to the "other" are all actors ' natural behavior ( Dedeoğlu, 2003: 55).

First of all, international security is definitely ahead of national security. Because the security of a state depends on the security of the entire international system. The increasing awareness of interdependence underscores the old liberal tradition of the belief that large threat perceptions and Armaments will lead to new imbalances and instability and ultimately undermine the security of all states within the system. This suggests that security should not only be self-reliant, but also include competitive interests. Moreover, the great threats of our age, such as terrorism and the proliferation of weapons of mass destruction, have a non-regional nature beyond nations. For this reason, they require international cooperation and risk management. This idea has revealed the concept of "common security" (General Staff Military History and Strategic Studies, 2003: 243).

\section{Democratic Peace Theory}

As the Cold War approached, researchers who believe that the arguments of classical liberalism for war and peace were unfairly ignored, such as Immanuel Kant, and the 18th-19th. argued that the views of republican writers and 19th-century liberal thinkers should be reinterpreted (Deudney, 2004: 315). Thus, to define international relations and to bring about ways to peace, a different way of benefiting from the accumulation of liberal thought was taken. 
The thinkers of the century 17.-18. had come up with the idea that a "community" or "Confucian Republic" could end the conflict between states. Although Jean Jacques Rousseau states that a world of republics would be a peaceful world, the thinkers of the period, including Rousseau, were pessimistic about establishing a peaceful environment between states and they believed that relations between states would continue to dominate interests and power (Zacher \& Matthew. 1995: 111). More optimistic about the possibility of progress in relations between states 18 . the end of the century, and 19th. it began to emerge in the century. Republican thinkers, who argued that wars emerged as a result of aristocratic regimes and mercantilist policies, began to claim that these problems could be eliminated by the spread of free trade. The most comprehensive analysis of these thinkers made Immanuel Kant in his "eternal peace" work written in 1795 (Zacher \& Matthew, 1995: 111).

Expressing his views on the way to peace between states, Kant said permanent peace is possible, especially among Republican administrations representing his people. At this point, many of Kant's ideas were published in the 19th century. It can be said that the 20th-century liberal thinkers differed from their ideas and Kant demonstrated the internal political structure of countries as well as free trade as a decisive factor to lead to peace (Doyle, 2000: 21). Among Kant's ideas, in particular, this issue began to be brought forward by democratic peace advocates led by Michael Doyle in the 1980s.

Beginning in the late 1970s, liberal writers began to assert more frequently that democracies did not fight each other, and therefore that "eternal peace" has been tried and proven among these countries of the world, that a partial World Peace, called "democratic peace" has been established (Henderson, 1999: 203).

The liberal international approach that links democracy and international peace has been named as "democratic peace theory" in the international relations literature. But it is more true to call him "democratic peace proposal" than to opposites of the approach. The main arguments of the democratic peace literature can be summarized as follows:

- There is democratic peace, that is, democracies have not fought each other (almost or not) in history.

- The reason for peace between democratic countries is the liberal democratic regimes of those countries.

This argument, which has not been dealt with in many democratic peace studies, but which has been accepted as tacitly and which is most concerned with our work, can be added to these arguments; democratic peace area expands with the rise of democratic states in the world and peace environment in the world is established with democracy in all states (Somuncuoğlu, 2009: 29).

The fact that the existing "democratic peace" is an important occupation in the discipline of international relations has resulted in the strong support of the theory by empirical studies as a result of the developments in statistical programs and computer technology and parallel with the creation of large databases of international conflicts. Numerous statistical studies led by Bruce Russett, John Oneal, and Zeev Maoz have shown that 
democratic countries have fewer armed conflicts among themselves than other countries. At this point, over a hundred empirical studies are supporting relatively peace between democratic countries (Ekmekçi, 2011: 109).

\section{Democracy-War Relationship}

To evaluate the theory of democratic peace, it is necessary to understand what the theory means with the concept of war. According to this, wars based on the generalizations and consequences of the theory are limited only by wars between states (Özdemir, 2007: 214). When examining the relationship between democracy and war, the following questions should be emphasized. Does the theory of democratic peace argue that democracies have never fought in the past and that they will not fight each other in the future, or does it mean that the Democratic states are fighting and threatened to use force against each other and that they will behave in the future, but are relatively peaceful for the system compared to other regimes? (Doğan, 2005: 607).

As mentioned earlier, the Theory of Democratic Peace refers to Kant itself but produces assumptions based on the proposition in a more limited and narrow frame than Kant suggests. Besides, democratic peace theory defines the struggles in which a thousand people have lost their lives as a war. It may be useful for conceptual explanations of determining Wars based on human losses, but such a definition has several problems. For example, it would not be right to classify an incident between the two states as a war, in which 999 people died. However, the main problem is the assumption of the theory. In this context, we can look at why the argument that democracies proposed by the Democratic Peace Theory are not going to fight each other in terms of causeeffect statements. It is known that two results were extracted from here. First, if there is a democracy, there is peace; secondly, if there is peace, there is democracy. As we can see, it is possible to put both democracy and peace in place as a cause. Therefore, it is seen that there is a correlation between both rather than a cause and effect relationship (Şahin, 2013).

Experts in war studies, Melvin Small and J. David Singer, 1816-1965 during the study of the wars between the years they studied the democratic countries during the time they found that they did not fight against each other. In the study, which found that the war was fought between neighbors, they observed that democratic countries were geographically far apart and that they were not neighbors and therefore did not act against each other. Another conclusion reached in the study is that democratic countries have the same degree of participation in war as other states (Singer \& Small, 1972). This research, Rudolph J.Rummel's work “Understanding Conflict and War" followed. In this five-volume study, Rummel focused on the relationship between democracy and violence. In contrast to Singer and Small, he found solidarity and peaceful tendencies between liberal states and societies (Rummel, 1982). The main interest in these works has always been the thesis that Democratic states are peaceful from others. However, a new democratizing country is much more prone to war than a settled democracy and authoritarian regimes. The tendency for this war in democratized countries is related to the approach of the elites in the struggle for power in an environment where democratic institutionalization is not mature enough and the fact that these states are closer to war and conflict in the international arena. (Usul, 2017: 17). 
So far, many studies have been carried out to prove that democratic countries have not fought each other in history. The democratic peace activists, who accepted that there were a few exceptions on the criticisms of the realist writers, tried to prove their claims with statistical studies. Some of these studies are 19. in the 20th century, the majority of the narrower time intervals have generally stood on the Cold War era (Maoz \& Russett, 1993: 628). A few studies have also examined the war and peace experiences of the past Republican administrations, including ancient times (Weart,1998). While statistical tests were carried out for most of these studies, some studies have only been compared to lists of "liberal regimes" and international wars in history (Doyle, 2000: 212). Statistical studies were testing the assumption that Democratic states did not fight each other. The general conclusion from these works is that at least one of the supporters must be authoritarian to be war (Rummel, 1983: 67).

The proponents of the DBT had a "determinist" attitude at first, and a generally valid argument that "Democratic states do not fight each other" they were defending. Such is the general view in early democratic peace theory literature that democratic peace is an "empirical law",(Levy,1988:662) and democracy is a" sufficient " reason for peace that meant (Gleditsch, 1995: 318). But the US-UK War of 1812, the US-Spain War of 1898, and criticism over conflicts between democratic countries such as the 1999 Kargil war between Pakistan and India has made it difficult to defend the theory of democratic peace as a determinist relation, and the theory of democratic peace has evolved into a "probability" argument (Farber and Gova,1997: 399). Today, the democratic theory of peace is understood as"democracy helps countries to pursue peaceful policies".

\section{Democracy-Peace Relations}

To understand the theory of democratic peace, it is necessary to clarify why democracy is more peaceful. Bruce Russett argues that the pursuit of peaceful and aggressive policies among themselves about other regimes could be explained in two ways: cultural/normative and structural/ institutional (Russett, 1993: 35). Cultural/normative reasons relate to the conduct of foreign policy based on a culture based on such methods as reconciliation, negotiation, and avoidance of violence that democracies develop within themselves. According to this, the officials who carry out foreign policy reflect the methods and norms they apply in their internal policy processes to foreign policy and expect them to behave the same way on the other side. Similarly, peaceful relations arise between democracies carrying out foreign policy based on avoidance, compromise, and compromise of violence. The reflections of a regime that recognizes the existence of different thoughts and groups and gives them a habitat are peaceful in foreign policy. The structural/ institutional reasons for democratic regimes not being able to act aggressively and hostile to other regimes are related to the distrust and suspicion of non-democratic regimes because of their lack of restrictive institutional structures and their tendency to not resort to violence. Democratic regimes tend to fight as much as other regimes, and they have fought as much as other regimes. However, in the last two centuries, they have rarely fought or never fought each other (Özdemir, 2007: 211).

According to Montesquieu, the proliferation and expansion of Democratic administrations around the world will be effective in ensuring the preservation of international peace. In democratic republics where the thought and 
will of the societies have reflected the government, the decision to enter the war will be taken by the cautious and careful society to protect its values, there is less chance of international war. Kant also states that the people who will be directly affected by the devastation and damage caused by wars will be very cautious about entering the war (Kant, 1939). As a result, States will not be able to wage war on other states only by the decision of a single leader or the ruling elite, and will often use their choice for a peaceful solution as a result of the cautious attitude and common reasoning of the people.

It is supported by empirical data that contribute to peace in the democratic way of political governance of a state. Oneal, Russett, and Berbaum had bilateral meetings with approximately ten thousand individuals from 18851992. An empirical study of the data they compiled in the context of the interview shows that democracy is among the three main factors that serve the establishment of peace. This study shows that the possibility of conflict between the two democracies is $86 \%$ less than that of the two parties and that the democratization process does not threaten international peace, in contrast to the general opinion (Oneal a.o, 2003: 387-388).

To explain the correlation between democracy and Peace, Studies in the literature of the Democratic Peace Theory have adopted democracy as an "independent" variable and have established a direct and one-way causal relationship between democracy and peace (democracy $\rightarrow$ peace). However, given the historical development of Western democracies, the relationship between democracy and peace can be a reverse causality (peace/democracy) relationship, or an imaging relationship (economic development $\rightarrow$ democracy + peace), in which both variables are determined as the main factor of economic development (Ekmekçi, 2011: 115).

Scholars arguing that the relationship between democracy and peace is not what they thought, argued that democracies have waged many wars and have fought many times with non-democratic countries and that democracies have inflicted a lower degree of violence on their own as well as on the societies of other countries. In response, critics and some realist writers claim that even solid democracies have violated human rights as much as authoritarian states against other peoples, even more, grievous than those of them. In this regard, Anatol Lieben cited human rights violations in India, as well as in France in the 1950s and the 1960s during the brutal struggles of the United States with guerrillas (Lieven, 2006: 244-245).

We witness recently that the use of military force has been justified, arguing that peace can be established with democratic values and that all states in the world can attain democratic regimes. Although academics try to scientifically understand the relationship between democracy and Peace, their ideas are sometimes used by international policymakers for their purposes. For this reason, the Liberals must remain sufficiently focused on the possible political consequences of the theory of democratic peace (Doğan,n.d.:609).

\section{International Security and Democratic Peace}

With the end of the Cold War and the acceleration of the process of globalization, the traditional security perception of the international system has ended and the world community has faced many different security 
challenges. First of all, the other (threat), which is defined and defined, disappeared, and instead emerged in the form of the non-state global organization. In general, the regimes of semi-organized movements, which carry economic, political, religious, ethnic characteristics and do not fully coincide with a state or public, have also emerged in the means of changing the behavior patterns of the peoples and political parties. The fact that all of the players are clearly defined and the vehicles are in a variety of untraceable forms has brought the area of the security problem to a wide range from individual to global stratification (Aydınlı and Roseanu, 2005: 43).

In today's international system, which makes security perceptions even more complex, the idea of transforming structural conditions that bring them to the fore has prevailed to eliminate the problems that pose a threat to security. Instead of killing mosquitoes, it's the idea of drying the swamp. What drives the international community to do this is to bring security, Collective and indivisible character, especially in the wake of the developments after September 11 (Cural, 2011: 51). After the attacks, the US government raised its argument that the September 11 attacks were an act not only against its own country but also against freedom and democracy. According to the US, terrorism is not the only goal in America. It is also democracy, freedom and human rights. Joint action should also be taken against those who target them. The United States has successfully globalized its national security on NATO ground within the framework of its friends and allies. In this way, international security concerns have begun to spread all over the world from the US agenda. The occupation of Afghanistan in 2002 was based on this threat and accepted by the international community. As part of the September 2002 National Security Strategy, the United States uses the concept of "preventive war" which is not included in international law as a legitimate instrument for national security in many international operations, including the invasion of Afghanistan and Iraq. In this context, military interventions are opened, all kinds of terrorist attacks, or rogue states, which are not included in international law, or failed states, are responded to attacks and activities, and all military operations are aimed at "spreading democracy" at the end of all these military operations (Tansi, 2005: 37).

Idealism assumes that there is a linear relationship between the concepts of democracy and peace. Based on this assumption, he argues that the security of Democratic states is based on more robust foundations. As a natural consequence of such an assumption, unlike the thesis that realism is similar units of each state, it treats states as separate units with their unique structures. For example, idealists argued that the most important security problem of the Cold War era was that the East Block was composed of non-democratic states and that their countries had a democratic structure and that international security problem would be considerably reduced (Kaldor, 1991: 318). The most concrete example to disprove this thesis of idealists is the aggressive policies of the United States during the post-Cold War period. The fact that a state, considered one of the world's leading democracies, is almost continuous in the post-Cold War period, refutes the thesis that there is a linear relationship between democracy and peace.

The contribution of social constructivists to the discipline of international relations, especially security studies, is the Democratic Peace approach. Social constructivists, based on the fact that there is no war between countries 
with democratic regimes in the light of historical data, are the concept of security that argues that democracies with a political identity will not fight each other. This theory, as a political regime and identity, has shown that democracies are reluctant to fight (Doyle, 1986: 1151). According to the Theory of Democratic Peace, institutional and normative limitations such as civil and political rights, elections, compromises, press, and freedom of opinion, or other characteristics that characterize the war decision contained within a democracy will result in the peaceful settlement of disputes between democratic countries not by violence or coercion but by peaceful means (Maoz \& Russett, 1993: 624). The Theory of Democratic Peace is especially important in terms of the global expansion of Democracies, and in terms of showing that global security problems will be reduced at the same rate. For Democratic Peace theoreticians, the stabilization of global democracies will be an important tool in establishing permanent peace, and they are not afraid to say that wars can be used as a means to achieve this stabilization. In particular, the Democratic Peace theoreticians who come from the view that a significant part of the global security crises after 1990 originate from the anti-democratic countries see foreign interference as legitimate in the delivery of these countries to democratic regimes. In particular, these groups argue that the United States's post-1990 security policies are based on the spread of Democracies and the preservation of the stability of existing democracies. The Theory of Democratic Peace provides historical data that strengthens social constructivism's claims that the characteristics of the demands such as "anarchy", "self-sufficiency", anxiety and "security dilemma" are not permanent and material but "social structures" and that states are built after mutual interaction (Kardaş, 2007: 125).

However, it should be added that many academics have argued that contrary to the contrary, Democratic states have found war among themselves essentially occurring, but liberal theoreticians have ignored it and have ignored claims against it that would disrupt the theoretical structure. It is claimed among the defenders of the theory that even the definition of the Liberal Democratic state or the political system cannot be unanimous and therefore the said theory cannot be supported by empirical data, and therefore they described the approach as "myth" rather than as a theory.

Another criticism of the Democratic Peace Theory relates to the definition of the concept of "democracy". The difficulty in making a clear definition of democracy is a problem (for example, Germany before the First World War is not considered democratic). Secondly, even if the definition of democracy is made clear, many say we have insufficient data to establish a causal relationship between democracy and peace. Thirdly, in the mind of many thinkers, democracies do not produce welfare and stability, but in countries with prosperity and stability, a democratic regime is established. Fourth, the definition of war is unclear. In democratic countries, civil wars and revolts, terrorist incidents can be experienced. Also, democratic countries from time to time may enter into relations with each other in the form of proxy war or cold war (Örmeci, 2016).

On the other hand, in terms of democratic governments, there is no doubt that it is more difficult to start wars or take certain risks related to war because of the relationship between death and the number of voters. It is said that when the Liberals have a democratic regime, they are a potential obstacle to the war of the people in 
the country. Because the administration of a country by a democratic government does not mean that the people in this country will always vote against the war, and even the people mentioned in person can vote for the war (Şahin ,2013).

The proposition that democracy leads to peace and stability among democratic regimes can be reversed as peace and stability allow democracy. Because, as the threats in the environment increase, the democratic nature of the regime decreases, while the countries whose security concerns are minimal are easier to adopt the democratic regimes. The question that needs to be answered carefully here is whether "democracy leads to peace " or whether the atmosphere of peace and stability creates democratic regimes?" the question is (Özdemir, 2007: 217-218).

Recent studies on democratic peace reveal that rapid political democratization, which does not deal with economic development and does not fall into the values of society, does not benefit in terms of peace, and even increase conflicts. "Developed liberal democratic countries do not fight each other" today, the proposal for the democratic peace, which has led to mobilization in the international relations literature, has turned into a form of "developed liberal democratic countries do not fight each other".

Despite the strong relationship between economic development, peace, and democracy, the numerical impact of economic development on peace and democracy research in the literature of democratic peace theory was only realized in the 2000s. Michael Mousseau's pioneering empirical work, in which he analyzed all countries together, States of the effect of democracy on reducing armed conflicts it has shown that it depends on levels of economic sophistication and that this effect is not seen in poor democracies. Later regional analyses by Henderson and Goldsmith revealed that the peaceful impact of democracy was limited to Western Europe and North America. The fact that democratic peace is on the border with developed Western countries in empirical research and the peaceful effects of economic development in the same research indicates that democratic peace can be an economic-based peace rather than a political one. Indeed, there is now a growing trend in the literature that democratic peace is a false representation and that peace between democratic countries is a “capitalist peace". (Ekmekçi, 2011: 118).

Today, the leading authors of the democratic peace proposal propose democratization that can be achieved through economic development and that allows democratic norms to be established. The latest research and tests on democratic peace today reveal that the theory of democratic peace can not be a guide to the policy of promoting democracy. Like realists, many democratic peace advocates today are concerned about the consequences of external democratization in terms of world peace. The recent studies that correlate liberal peace and economic development almost underscore the uniqueness of the Western states and the current peace situation between them. However, the claim of democratic peace is used to base U.S. foreign policy, as it was first introduced and even simplified. Although the theory of democratic peace is far from explaining the wars and conflicts between democratic states and non-democratic states during the post-Cold War period (US intervention in Afghanistan and Iraq), it has helped legitimize them. 


\section{CONCLUSION and DISCUSSION}

Democratic peace theory is one of the most controversial and studied theories in the discipline of international relations over the last three decades. At this point, relatively peace between developed democratic countries is undeniable as a fact. But the source of this peace is the political regime (democracy). First of all, there is no "democratic peace" other than the developed Western countries. Besides, developed Western democracies are a combatant as non-democratic countries in their dealings with other countries. Therefore, peaceful mechanisms of democracy do not work against countries outside Western countries. Another important point is that developed Western democracies have fought many times with disguised wars, not directly with the democratic countries of the third world, when their interests require them (Ekmekçi, 2011: 119). Recent studies on democratic peace show that rapid political democratization, which does not deal with economic development and does not fall into the values of society, does not benefit from peace and even increase conflicts. Also, democratization shows that many Western countries use illegal procedures as a means of legitimizing them.

Realism claims that by defining the selfish, passion for power and competitive structure of human nature at the root of the conflicts (by projecting to this day, Western states of the day will act in their interests). The Neorealist definition of Neorealist by Kenneth Waltz, The Architect of Neorealist though, contradicts the view that by Western states, in particular the United States, they are seeking their right in the form of struggle for survival through the current process of international security and democratic peace.

The concept of security in liberalism defense of the territory of the country and more military activities aimed at ensuring the country's survival more refers. The concept of power and therefore the phenomenon of security is reused by the fact that the bipolar world order is replaced by the multipolar system of balances interpreted; broadened scope. In this context; the current military dimension, as well as political, economic, social and technological dimensions, have gained importance. The liberalism finds the balance of power in this new world order, in a wide range of freedoms and economic structure. In this context, the future new security environment will depend on countries ' ability to fight global terrorism, democratize and achieve their economic development (Çetinkaya, 2012: 252).

The arguments put forward by the Liberal democratic theory of peace, contrary to what is thought, have no validity. As in Iraq and last but not least in Mali The interventionism of Western states is widely known. Moreover, the incident of non-war in Western Europe is misdiagnosed. Zira West The US protection and security guarantee on Europe remains in effect. Therefore, II in Western Europe. Post-World War II Reigns peace climate, without the U.S. Factor, only democratic values and institutions it is impossible to explain with its acquisition and stability (Büyükbaş \& Atıcı, 2012:15).

Another issue to focus on, especially after the Cold War it is the war trend of the states going through the democratization process during the period. As evidenced repeatedly since the late 1980s, states that are beginning to democratize are often too volatile and dangerous they have a structure. These states where 
democratic culture has not yet settled they find themselves " far more than mature democracies and/or stable authoritarian states they may often find themselves in conflict (Mansfield \& Snyder, 1995: 85).

Another criticism is that peace is not the peace of democracy but the democracy of peace he talks about what he produces. In other words, democracy is the peace it's not a cause, it's a consequence. This criticism is one of many since 1945 misleading democratic peace proposition of key foreign policy decisions information received as a result of, and ultimately including, the 2003 Iraq War he argues that it causes many wars to be (Özkeçeci, 2019: 4).

As a result, democracy and democratization efforts, one of the tools used to address international security problems and concerns, are insufficient to solve these problems, many violations and occupations are done using the name of democracy.

\section{ETHICAL TEXT}

"In this article, journal writing rules, publication principles, research and publication ethics rules, Journal ethics rules have been adhered to. The author is responsible for any violations that may arise related to the article."

\section{REFERENCES}

Ağır, B. (2011). "Güvenlik Kavramını Yeniden Düşünmek: Küreselleşme, Kimlik ve Değişen Güvenlik Anlayışı". Güvenlik Stratejileri, 22: 97-131.

Aydınlı, E.\& Rosenau, J. (2005). Globalization, Security and the Nation State: Paradigms in Transition. New York: New York Press.

Ayoob, M. (1994). "Security in the Third World: Searching Forth the Core Variable", Norman A. Graham (com.) Seeking Security and Development -The Impact of Military Spending and Arms Transfers. USA: Lynee Reinner Publishers.

Baldwin, D. (1997). "The Concept of Security". Review of International Studies, 23: 5-26.

Baldwin, D. (2003). “Güvenlik Kavramı”. Avrasya Dosyası Güvenlik Bilimleri, 9(2): 5-35.

Buzan, B. (1991). People, States and Fear: An Agenda for International Security Studies in Post-Cold War Era. News York: Harvester Wheatsheaf.

Buzan B. (1998). Security: A New Framework For Analysis. London: Lynne Rienner Publishers

Büyükbaş, H. (2012). " Liberal Demokratik Barış Kuramı: Eleştirel Bir Değerlendirme". Erciyes Üniversitesi Iktisadi ve Idari Bilimler Fakültesi Dergisi, 40: 1-19.

Cural, A. (2011). Bush Doktrini ve Askeri Gücün Önalııı ve Önleyici Savaş Kapsamında Kullanılması, Yayınlanmamış Doktora Tezi, Ankara Üniversitesi Sosyal Bilimler Enstitüsü, Ankara.

Çetinkaya, Ş. (2012). "Güvenlik Algılaması ve Uluslararası Ilişkiler Teorilerinin Güvenliğe Bakış Açıları”. 21. Yüzyıda Sosyal Bilimler, 2: 241-260.

Dedeoğlu, B. (2003). Uluslararası Güvenlik ve Strateji. İstanbul: Derin Yayınları. 
Deudney, D. (2004). “Publius Before Kant: Federal-Republican Security and Democratic Peace”. European Journal of International Relations, 10(3): 315-356.

Dixon, H. (1995). “On The Threeshold - Environmental Changes as Cause of Acute Conflict” Sean M. Lynn (Com.) Global Dangers -Changing Dimensinos of International Security. Cambridge: MIT Press.

Doğan, N. (2007). “Demokrasi ve Orta Doğu'nun Geleceği”, 13 Şubat 2019 tarihinde http://www.ayk.gov.tr/wpcontent/uploads/2015/01/DO\%C4\%9EAN-Nejat-DEMOKRAS\%C4\%BO-VE-

ORTADO\%C4\%9EU\%E2\%80\%99NUN-GELECE\%C4\%9E\%C4\%B0.pdf, adresinden alınmıştır.

Doyle, M. (2000). "Peace, Liberty and Democracy: Realists and Liberals Contest a Legacy”, Michael Cox (Com). American Democracy Promotion: Impulses, Strategies, and Impacts. New York: Oxford University Press. Doyle, M. (2000). “Liberalism and Word Politics”. American Political Science Review, 80: 1151-1169.

Ekmekçi, F. (2011). “Demokratik Barış Teorisi: Bir Değerlendirme”. Uluslararası Hukuk ve Politika, 7(26): 107-124.

Farber H. \& Gowa J., (1997). “Common Interests or Common Polities? Reinterpreting the Democratic Peace". The Journal of Politics, 59(2): 393-417.

Farnham, B. (2003). "The Theory of Democratic Peace and Threat Perception". International Studies Quarterly, 47:395 - 415 .

Gjejlani, E. (2007). Değişen Uluslararası Güvenlik Bağlamında Yugoslavya'nın Dağılması ve Kosova'nın Nihai Statü Sorunu. Yayınlanmamış Yüksek Lisans Tezi, Uludağ Üniversitesi Sosyal Bilimler Enstitüsü, Bursa.

Gleditsch, P. (1995). “Geography, Democracy and Peace”. International Interactions, 20(4) :302-328.

Henderson, E. (1999). "Neoidealism and the Democratic Peace", Journal of Peace Research, 36(2):203-231.

İşyar, Ö. (2008). “Günümüzde Uluslararası Güvenlik Stratejileri: Kavramsal Çerçeve ve Uygulama”. Akademik Bakış, 2(3): 1-42.

Kant, I. (1795). “Toward Perpetual Peace: A Philosophical Sketch" 12 Aralık 2018 tarihindehttps://archive.org/stream/perpetualpeaceph00kantuoft/perpetualpeaceph00kantuoft_djvu. txt adresinden alınmıştır.

Kaldor, M. (1991). "Rethinking Cold War History". Ken Booth (Com). New Thinking About Strategy and International Security. London: Harper Collins Academic.

Kegley, C. (1995). “Neoliberal Challenge to Realist Theories of World Politics: An Introduction”. Charles W.Kegley (Com.). Contraversies in International Relations Theory, Realism and the Neoliberal Challenge. New York: St.Martin's Press.

Kıyıcı, H. (2012). Uluslararası iliş̧kiler Teorilerinde Güvenlik Kavramı. Yayınlanmamış Yüksek Lisans Tezi, Akdeniz Üniversitesi Sosyal Bilimler Enstitüsü, Antalya.

Krause, K.\& Williams,M. (1996). "Broadening the Agenda of Security Studies: Politics and Methods". Mershon International Studies Review .40(2): 229-254.

Küçük, M. (2009). “Uluslararası İlişkiler Kuramında Konstrüktivist Dönüş”. Ege Academic Review, 9(2): 771-795.

Levy, M. (1995). “Is the Environmental a National Security Issue?”. International Security, 20(2): 35-62.

Levy, J. (1988). “Domestic Politics and War". Journal of Interdisciplinary History, 18(2): 640-674. 
Lieven, A. (2006). "Wolfish Wilsonians: Existential Dilemmas of the Liberal Internationalists". Orbis, 50(2): 243257.

Lind, M. (2006). The American Way of Strategy: U.S. Foreign Policy and The American Way of Life, U.S: Oxford University Press.

Mansfield, E.D.\& Snyder, J. (1995). “Democratization and War”. Foreign Affairs, 74(3): 79-97.

Masala, C. (1999). “Demographic Pressure and Ecological Restraints: The Case of Mediterrian”. Kurt R. Spillman (Com.). International Security Challenges in a Changing World. Bern: Peter Lang.

Maoz, Z.\& Russett, B. (1993). “Normative and Structural Causes of Democratic Peace, 1946-1986”. The American Political Science Review, 87(3): 624-638.

Miller, B. (2001). "The Concept of Security: Should it be Redefined?". The Journal of Strategic Studies. 24(2): 13-

42.

Mütercimler, E. (2001). “Değişen Güvenlik Kavramı ve Küresel Stratejiler”. Savunma ve Strateji Dergisi,97: 17-

25.

NATO 2020: Assured Security; Dynamic Engagement Analysis and Recommendations Of The Group of Experts On

A New Strategic Concept For Nato, NATO, Brüksel, 17 Mayıs 2010.

Oneal, J.(a.o). (2003). “Causes of Peace: Democracy, Interdependence, and International Organizations, 18851992". International Studies Quarterly, 47(3) :371-393.

Örmeci, O. (2016). “Demokratik Barış Teorisi”. 14 Şubat 2019 tarihinde http://politikaakademisi.org/2016/10/14/demokratik-baris-teorisi/ adresinden alınmıştır.

Özdemir, H. (2007). “Demokratik Barış Teorisi”. Haydar Çakmak (Der.). Uluslararası iliş̧kiler Giriş, Kavram ve Teoriler, Ankara: Platin Yayınları.

Özkeçeci T. (2019)., “Demokratik Barış”, Güvenlik Yazıları Serisi.7:1-5.

Rummel, R.J. (1983). “Libertarianism and International Violence”. Journal of Conflict Resolution, 27: 27-71.

Russett, B. (1993). Grasping the Demopctaic Peace. New Jersey: Princetion University Press.

Small, M. \& Singer D. (1982). Resort to Arms: International and Civil War,1816-1980. Beverly Hills: Sage.

Somuncuoğlu, A. (2009). A.B.D’nin Demokrasi Özendirme Politikası: Kazakistan Örneği. Yayınlanmamıs Doktora Tezi, Ankara Üniversitesi Sosyal Bilimler Enstitüsü, Ankara.

Şahin, K. (2014) “Demokratik Barış Teorisi'nin Argümanlarına Yönelik Eleştiriler”. 11 Kasım 2018 tarihinde http://akademikperspektif.com/2013/04/01/demokratik-baris-teorisinin-argumanlarina-yonelikelestiriler/ adresinden alınmıştır.

Tansi, D. (2005). “A.B.D.'nin Ulusal Güvenlik Anlayışı ve Türkiye”. Jeopolitik Dergisi, 46: 25-37.

Tavas, T. (2011). Uluslararası Güvenlik Sisteminde Değişim: Kolektif Müdahale Doktrinin Yükselişi. Yayınlanmamış Doktora Tezi, Gazi Üniversitesi Sosyal Bilimler Enstitüsü, Ankara.

Usul, A. (2014). "Demokrasi, Otoriterlik, Uluslararası Politika: Entegre Bir Yaklaşım Arayışı”. 10 Ocak 2019 tarihinde http://sam.gov.tr/tr/demokrasi-otoriterlik-uluslararasi-politika-entegre-bir-yaklasim-arayisi/ adresinden alınmıştır.

Walt, S. (1991). "The Renaissance of Security Studies". International Studies Quarterly, 35(2): 212-225. 
Waltz, K. (1992). "Realist Thought and Neorealist Theory”. Robert L. Rothstein (Der.). The Evolution of Theory in International Realtions. S.Carolina:University on South Carolina Press.

Weart, S. (1998). Never at War: Why Democracies Will Not Fight One Another. New Haven: Yale University Press.

Zacher, M., Mattehew, R. (1995). “Liberal International Theory: Common Threads, Divergent Strands". Charles W. Kegley (Der.). Controversies in International Relations Theory: Realism and the Neoliberal Challenge. New York: St. Martin's Press. 